\title{
The Reflection of Maslow's Hierarchy Needs Theory in English Writing Teaching Circumstance
}

\author{
Xiao Wang \\ School of Foreign Languages \\ Huanghe Science and Technology College \\ Zhengzhou, China
}

\begin{abstract}
Maslow's hierarchy of needs is a theory in psychology proposed by Abraham Maslow in his 1943 paper "A Theory of Human Motivation" in Psychological Review. It is an important theory in the development of humanistic psychology. This thesis is try to provide the new interpretation of this theory in the circumstance of teaching process of English writing, so as to make some reform and innovation in the English Teaching .Meanwhile, it can arouse the students' $s$ interest and improve their writing ability.
\end{abstract}

Keywords-Abraham Harold Maslow; English Writing Teaching; New Interpretation

\section{INTRODUCTION}

The weak efficiency of College English writing teaching has been existed for a long time. Students always accustomed to recite the model sentence and essay, but never flexibly put the theories into use, which include English writing, vocabulary, syntax and sentence structure. To some degree, teaching of English writing is in trouble. To change this situation, we should find the new teaching theories and methods . Maslow's hierarchy of needs is a theory in psychology proposed by Abraham Maslow in his 1943 paper "A Theory of Human Motivation" in Psychological Review. It is an important theory in the development of humanistic psychology. To apply this theory in the teaching of college English writing, it can stimulate students' interest in learning, enhance students' English writing ability and improve their overall writing.

\section{The BASIC MeAning of Maslow' S HiERARChy OF NEEDS THEORY}

Maslow believed that motivation is the intrinsic power of individual development. It is composed of five different natures of needs, which is distinguished in sequence and level. These five needs are: physiological needs, security needs, love and belonging needs, respect needs and selfactualization needs. Physiological needs are the most primitive human needs; it is inevitable and fundamental needs. They are strong driving force to promote people to real action. For example, food, clothing, shelter, means of traveling and sex. Security requirements are more advanced than physiological needs. When the physiological needs are met, we must ensure the implementation of this need. Such as a person to need the sense of security, people are burned to have the desire of freedom. Belonging and love needs are also called the social needs. It refers to the individual' $s$ desire for concern and understanding from family, friends, colleagues .That is to say; people need friendship, love, trust and warmth. Need to respect, just as its name implies, is human need to get respect including self respect, self assessment and respecting others. It is rarely fully satisfied, but the basic implementation can produce some certain impetus. Self-actualization needs are the highest level of needs. This need is to complete the task with full potential and to do everything they can to be perfect [1]. These five kinds of hierarchy of needs are implemented step by step from low to high. Only when the low level satisfied, it can achieve high levels of driving force. Low level will not disappear after the implementation of the senior level. Meanwhile, He thinks that human demand is different from the instinct of the animas. It is human nature to realize one' $s$ need, it' $s$ dominated by consciousness. It' s purposeful and creative [2]. Despite that Maslow's theory have different views at home and abroad, but it' $s$ undeniable that it also has a certain practical significance.

\section{NEW INTERPRETATION IN THE TEACHING OF ENGLISH WRITING}

\section{A. Master the Basic Vocabulary-Physiological Needs}

In English teaching, the basic requirement of the student is the comprehensive improvement of listening, speaking, reading and writing ability. And the improvement of writing is the fundamental one. In English writing involves every detail of the English knowledge chain from the choice of words, the establishment of the structure and even the organization to the final clue. Misunderstanding, improper use of the Vocabulary, improper use of grammar or unreasonable layout would seriously affect the quality of the passage. According to Maslow's hierarchy of needs theory, master enough vocabulary is a minimum level of need in English learning. Therefore, if we want to improve the students' writing ability, we must expand their vocabulary, Which including a comprehensive introduction of vocabulary usage, related extension of commonly used phrases and vocabulary, the deformation of the words such as synonyms, antonyms or synonyms. The urgency to obtain knowledge is just like physiological needs for students, it is the most pressing part. In daily English study, students will 
gradually accumulate their own vocabulary. This is a doubleedged sword. When enlarging the vocabulary, student may feel even confused with the words have similar formation. Due to the impact of examination-oriented education for a long time, some students just remember the Chinese meaning of vocabulary, but ignore the English words to explain, which lead to the failure of word choosing during the process of writing. In English teaching, the author try to select some interesting topics, such as the reference of the tiger mother example, discuss the different Chinese and western family education. When discussing this topic, the author will provide some similar education psychology like "advance organizer". Make the migration effect happen on the basis of their previous vocabulary. The following words will be provided: critic, generosity, social conscience, food chain, reach one' $\mathrm{s}$ full potential, financially independent, controversial, etc. In the English writing teaching, we should not only teach students some fragmentary phrase sentence and not just the language learning, but through language, we can cultivate students' divergent thinking ability.

\section{B. Express Yourself Correctly and Accurately-Security Needs}

Security needs, that is, the sense of security. If reflected into the process of English learning, it is the process of getting pleasure and satisfaction. When mastering a certain number of words, the students' writing enthusiasm will be gradually increased, the motivation will be strengthened, and they will be more patient to devote in English learning. After mastering a certain vocabulary, they will get the sense of security. But it is temporary, and then there will be a new "conflict" to resolve [3]. That is complete and correct sentence writing, and also raising the richness of essay content. After the vocabulary improvement, they tried to use these new phrases and vocabulary. But how to express them freely will become a new problem. In the author's teaching practice, I often give students a lot of sentences. When talking about "Tiger mum", I will make the leading-in in the form of "Presentation" to introduce her to the students. I will introduce her point of view, her specific aspects of family education, the achievements of her child, and how she did to integrate Chinese and western cultural differences in family education. In the process of Presentation, I will write on the blackboard about the viewpoint or supporting details, which enable students to express their views in standard English after a great deal of background knowledge. After that, the students will have strong sense of satisfaction, which is the security needs according to Maslow. Before entering university, most students are under the supervision of parents and teachers to learn English for the college entrance examination; their self-management ability is comparatively weak. In college, because of different living habits and learning environment, students may have psychological discomfort. Some students therefore produce anxiety and depression, thus influence the development of their own. Anxiety is the individual whose anticipation can't reach the goal or can' $t$ overcome these barriers, which make the failure of self-esteem and self-confidence, or increase the sense of failure and guilt and nervousness English learning anxiety in English learning is very common. High levels of anxiety can make the person excessive unrest, thus reduce cognitive ability of their own. If the anxiety level is too low, it will make the person lack of enthusiasm and sense of security. Therefore, teachers should try to guide college English learning of students, help them relieve anxiety, and adapt to college English teaching as quickly as possible.

\section{Freedom of Expressing in a Group and the Recognizing - Love and Belonging Needs}

The need of belonging and love can be understood as the sense of belonging and other feelings through the interaction in English writing class. In the author's writing teaching, I usually divide the students into two groups. Such as the teaching case of "Tiger mum", after the general introduction of the Tiger mother, I give students the chance of selfexpression. It will improve their oral English in the group discussing, and it's also a good chance of "Brain storm". The students will have collision sparks in the positive statement, and they can learn from each other the different expression of the same meaning. If the idea of the lesson need "Debating", then the students will actively cooperate, brainstorm, and then everyone's ideas are combined to a general statement. This also greatly stimulates the students' interest in learning; enable them to actively participate in the writing. They are complementary with each other and inspire their thinking mutually in the team activities. In class, the teacher can organize the student to carry on the inquiry learning group. Outside the classroom, the teacher can organize the students to set up English club, or English interest group, and strive to cultivate the students' sense of belonging. This will stimulate the learning enthusiasm of the English better, improve the practice ability, and enhance the level of English.

\section{The Timely Encouragement in the Process of Study- Respect Needs}

In Maslow's theory, "Respect need" is self-respect, selfassessment, respect with others. The teacher plays an important role in this area. In the writing class, some students are introvert, and they are not positive to express their views. Usually after fierce ideological struggle, they begin to keep up courage to speak in front of the whole class. So whatever the expression of students, whether the use of words is rich, the teachers should give students timely encouragement, so that they get the teacher's recognition and respect. In the future classroom interaction, they are willing to participate actively. But if didn't get recognition and respect from teachers and classmates in writing class for a long time, later he will not have the courage to participate in class activities, while the efficiency of the English writing class and the teaching effect will be influenced greatly [4]. In addition to classroom speech, the author will give students "Homework" after the end of each lesson. After the assignments handed in, they can modify the article word for word. Through the teacher's corrections and comments, students will have the self-assessment and gain respect. It's very important for students' learning interest of the role. When they do the presentation in teamwork and group discussion, the teacher should give students more encouragement, make students establish confidence in learning and gain the respect 
gradually. In college English teaching, teachers' motivation for learning emotion is very important. Interest is the best teacher. Teachers should attempt to stimulate students' learning needs and aesthetic needs, guide the students to appreciate the beauty of the English language, and cultivate interest in learning. Such as guide students to appreciate the beauty of the English songs, enjoy the beauty of the English movie, imitate the English pronunciation, etc.

\section{E. Improvement of English Comprehensive Ability $\longrightarrow$ Self- Actualization Needs}

Teaching of English writing is quite different from teaching in other disciplines, not a utilitarian. It is a coherent system [5]. So it is not separate to improve the students' writing ability in the English writing teaching, but the overall ability. Richness of vocabulary in writing has a certain role in promoting listening, reading and other various abilities. At the same time many different topics are discussed in writing class, such as Haze, Confucius Institute, AIDS, Gender equality, Disadvantaged groups, etc. They can only improve the students' writing level, but also produce certain effect to the students' outlook on life and values, which enables the students to learn about their life "confused", and actively to solve the problems. It also has certain effect on college students' moral education. After the comprehensive progress, the students will no longer fear for writing class, and no longer recite a few model essays, but learn to express their views actively. The content and connotation of their essays will be improved. This is the highest state of English writing teaching. Self-actualization needs, is the realization of manipulative potential ability. This trend is said to be that people finally become the desired character, and do everything that is commensurate with their own abilities. Everyone has the need of self-realization, in college English teaching; teachers make the efforts to meet the needs of the students' self-realization. Teachers in the teaching should create conditions for maximum possibilities of realizing the students' self-actualization. For example, teachers can encourage students to take part in the speech contest for those who have English speaking skills, the students with performance specialty joint in the drama, and also they can recommend students to have the internship in the foreign companies. Maslow's "self-actualization" is the development of people's overall health; this is the starting point of education, and also the ultimate goal of education. If students have healthy psychology and sound personality, nature, the internal demand of "self-realization" is well-prepared.

\section{THE ENLIGHTENMENT OF ENGLISH WRITING TEACHING FROM THE HIERARCHY OF NEEDS THEORY AND THE CORRESPONDING IMPROVEMENT}

English teaching practice in the future, according to Maslow's hierarchy of needs theory, should firstly meet the needs of low level that is to enrich the students' writing vocabulary and sentence patterns. We should widen students' view and knowledge and find some acquainted topic to make students can actively participate in discussions, and after the interaction of teaching and learning, they can finally improve students' writing ability. In Maslow's theory, the low level can produce satisfied to achieve high levels of driving force. But after the implementation of senior level, the low level will not disappear. So only after the buildup of selfconfidence, it can motivate the high-level needs; thereby promote constantly progress in English learning ${ }^{[6]}$.

In the English writing teaching, in addition to provide some topics which can arouse their interest in the class, as an English major ,the students should also master some basic theory of writing. This is the basic professional quality as English major. So in English writing teaching, the teachers should put some theoretical knowledge into the writing subject. Make sure that the content is not too boring, but avoiding the lack of basic theoretical knowledge during the class period.

\section{REFERENCES}

[1] Wenling Wu."Discussions on the Students' Monthly Consumption Satisfaction Based on Maslow Theory". China metallurgical education . 2010

[2] Wenling wu."the Applying of Maslow Theory in Students Satisfaction Index Model". China Electric Power Education . 2009

[3] Michael Kremer,Edward Miguel.Incentives to Learn. . 2004

[4] Eric S.Maskin.Roy Radner and Incentive Theory. . 2001

[5] Wang Ping."the Connotation of University Intangible Assets and Evaluation Method". Journal of Fuzhou University (Philosophy and Social Sciences) . 2005

[6] Maslow AH.A theory of human motivation. Psychological Review . 1943 